\title{
PHYTOCHEMICAL ANALYSIS AND BIOLOGICAL ACTIVITY OF EXTRACTS OF LICHEN PHYSCIA SEMIPINNATA: AS A NEW SOURCE OF PHARMACOLOGICALLY ACTIVE COMPOUNDS
}

\author{
JOVICA TOMOVIĆ ${ }^{1}$, MARIJANA KOSANIĆ ${ }^{2}$, BRANISLAV RANKOVIĆ ${ }^{2}$, PERICA VASILJEVIĆ ${ }^{3}$, \\ STEVO NAJMAN $^{4}$, NEDELJKO MANOJLOVIĆ $^{1 *}$ \\ ${ }^{1}$ University of Kragujevac, Serbia, Faculty of Medical Sciences, Department of Pharmacy, 34000 Kragujevac, Serbia \\ ${ }^{2}$ University of Kragujevac, Faculty of Science, Department of Biology, 34000 Kragujevac, Serbia \\ ${ }^{3}$ University of Niš, Serbia, Faculty of Science, 18000 Niš, Serbia \\ ${ }^{4}$ University of Niš, Serbia, Faculty of Medicine, 18000 Niš, Serbia
}

*corresponding author: mtnedeljko@gmail.com

Manuscript received: October 2018

\begin{abstract}
The present study provides new data concerning chemical characterization and biological activity of acetone, methanol and aqueous extracts of the lichen Physcia semipinnata. Chemical profiling of the extracts was done by high-performance liquid chromatography coupled with a UV detector (HPLC-UV) analysis. The antioxidant activity was evaluated by measuring total anti-oxidative capacity, reducing capacity, inhibition lipid peroxidation and scavenging capacity on 2,2-diphenyl-1picrylhydrazyl (DPPH) and hydroxyl $(\mathrm{OH})$ radicals. In vitro anticancer activity was evaluated by 3-(4,5-dimethylthiazol-2yl)-2,5-diphenyltetrazolium bromide (MTT) assay. Lecanoric acid, methyl- $\beta$-orcinol carboxylate, ethyl haematommate, evernic acid, obtusic acid and atranorin were identified from this lichen. As a result of the study of the antioxidant activity, the acetone and the methanol extracts of $P$. semipinnata was found to have the better antioxidant activity than aqueous extract. Total phenolics and flavonoids in the extracts were determined spectrophotometrically, with the varied amount from 20.11 to $59.20 \mathrm{mg} \mathrm{GA} / \mathrm{g}$ and from 5.48 to $19.27 \mathrm{mg} \mathrm{RU} / \mathrm{g}$, respectively. The results of the viability and proliferation study of HeLa, LS174 and A549 cells after the treatment with the extracts showed that the best cytotoxic/cytostatic activity was exhibited by the acetone extract of $P$. semipinnata. Investigated extracts can be used as natural antioxidant agents and as a significant source of biological active compounds.
\end{abstract}

\section{Rezumat}

Prezentul studiu oferă noi informații privind caracterizarea chimică şi activitatea biologică a extractelor apos, metanolic şi acetonic ale lichenului Physcia semipinnata. Profilele chimice ale extractelor au fost realizate prin cromatografie lichidă de înaltă performanță cu detecție în UV (HPLC-UV). Activitatea antioxidantă a fost evaluată prin măsurarea capacității totale antioxidante, capacitatea de reducere, inhibarea peroxidării lipidice și capacitatea de chelatare a radicalilor 2,2-difenil-1picrilhidrazil (DPPH) și hidroxil $(\mathrm{OH})$. Activitatea anticanceroasă in vitro a fost evaluată prin testul bromurii de 3- (4,5dimetiltiazol-2-il) -2,5-difeniltetrazoliu (MTT). Acidul lecanoric, carboxilatul de metil- $\beta$-orcinol, hematomatul de etil, acidul evernic, acidul obtusic şi atranorina au fost identificate în acest lichen. Ca rezultat al studiului activităţii antioxidante, s-a descoperit că extractele metanolic și acetonic de P. semipinnata au o activitate antioxidantă mai bună decât extractul apos. Conţinutul total în fenoli şi flavonoidele totale s-au determinat în extracte spectrofotometric, variind de la 20,11 până la 59,20 mg GA/g și de la 5,48 până la 19,27 mg RU/g, respectiv. Rezultatele studiului de viabilitate și proliferare a celulelor HeLa, LS174 și A549, după tratamentul cu extracte, au arătat că cea mai bună activitate citotoxică/citostatică a fost prezentată de extractul obținut în acetonă din P. semipinnata. Extractele investigate pot fi folosite ca agenți antioxidanţi naturali şi ca o sursă importantă de compuși biologici activi.

Keywords: HPLC, lichen metabolites, cytotoxic activity, antioxidant activity

\section{Introduction}

Examination of chemical and biological properties of natural products used in traditional medicine all over the world has resulted in many therapeutic agents that are used today in modern medicine [28]. Lichens have been used since ancient times in traditional medicine in cultures around the world. The lichens synthesize a large number of different secondary metabolites and most of them are unique to the lichen. These are mainly monoaromatic compounds, pulvinates, depsidones, depsides, anthraquinones, xanthones and dibenzofurans [4]. Lichens have shown a wide spectrum of biological potential, but have long been neglected by the micro and pharmaceutical industries due to their slow growth and difficulties in their artificial cultivation [27]. Interest in secondary metabolites from the lichens is constantly increasing. However, a relatively small number of lichen metabolites are isolated and their biological activity 
FARMACIA, 2019, Vol. 67, 2

and therapeutic potential are tested for their difficulty in obtaining them in a greater amount and purity that will be sufficient for structural determinations and pharmacological tests [3]. The secondary metabolites of the lichens exhibit antimicrobial, antioxidant, anti-inflammatory, antitumour, analgesic, antipyretic, antiviral effect $[10,11,23,27]$. The special significance of this study lies in the fact that, until now, there is very little data on the chemical composition, antioxidant and cytotoxic activity of the lichen Physcia semipinnata (J. F. Gmel.) Moberg. Thus, the aim of this study is to present the results of the mycochemical analysis of the acetone, methanol and aqueous extracts of $P$. semipinnata lichen and its antioxidant and cytotoxic activities in order to find an easily accessible source of natural biological agents that could be used as a possible food supplement, in the pharmaceutical industry and in the treatment of various diseases.

\section{Materials and Methods}

Collection and identification of lichen sample Lichen was collected at the site of the eastern slope of the mountain Kopaonik on the territory of the Republic of Serbia. Specimens of the types of lichen: Physcia semipinnata (J. F. Gmel.) Moberg was determined at the Department of Biology and Ecology, Faculty of Natural Sciences and Mathematics, the University of Kragujevac, Serbia, using the relevant key and monographs [5, 26].

Preparation of the lichen extracts

The dried material of the selected types of lichen is crushed to a coarse powder (2 - $6 \mathrm{~mm})$, using a mill. Thereafter, a separate extraction (4 hours) was performed with acetone, methanol and water using the Soxhlet apparatus. For the extraction, $100 \mathrm{~g}$ of the investigated sample of lichen and $300 \mathrm{~mL}$ of solvent were used. Evaporation of the solvents used for the extraction was performed under reduced pressure on the rotary vacuum evaporator (IKA). In this way, dry extracts were obtained, which were stored in dark glass bottles and used for further testing.

High-performance liquid chromatography (HPLC) analysis

HPLC with UV detection was used to expand and identify individual constituents of extracts. Analyzes were performed on the Agilent 1200 Series using the C18 column (ZORBAX Eclipse XDB-C18; $25 \mathrm{~cm} \times$ $4.6 \mathrm{~mm} ; 5 \mu \mathrm{m})$. Separate dot detection was be performed using a Diode Array Detector (DAD) detector at 280,330 and $350 \mathrm{~nm}$, and the absorption spectra of the components were recorded in the range of 200 to $400 \mathrm{~nm}$. Dissolved solubilized samples were filtered through using a pore size of $0.45 \mu \mathrm{m}$. Chromatographic separation was carried out using acetonitrile:water:phosphoric acid solvent system (90:10:0.1, v/v/v). The mobile phase flow rate was $1 \mathrm{~mL} / \mathrm{min}$. The column was thermostated at a temperature of $300^{\circ} \mathrm{C}$. Identification of individual constituents of the extracts were made by comparing the retention times $\left(t_{R}\right)$ and UV spectra of constituents with standards $(\lambda=200-400 \mathrm{~nm})$. The standards used were obtained from the following sources (from our own studies): evernic acid and atranorin are isolated from the Evernia prunastri, obtusic acid is isolated from Ramalina obtusata, lecanoric acid isolated from the lichen Parmotrema tinctorum, methyl- $\beta$-orcinol carboxylate and ethyl haematommate are isolated from Pseudevernia furfuracea.

Determination of total polyphenols content

The total content of polyphenols in the extracts was determined with the Folin-Ciocâlteu reagent, by the spectrophotometric method [24]. Briefly, the volume of $0.5 \mathrm{~mL}$ of the extract $(1 \mathrm{mg} / \mathrm{mL})$ is mixed with $2.5 \mathrm{~mL}$ of Folin-Ciocâlteu reagent and with $2.5 \mathrm{~mL}$ of $\mathrm{Na}_{2} \mathrm{CO}_{3}$ solution $(7.5 \%)$. The quantitative estimation of polyphenols was performed by measuring the absorbance at $760 \mathrm{~nm}$. The content of the total polyphenols was calculated using an equation obtained from a standard gallic acid calibration curve $(y=0.007 x$ total polyphenols [mg GA/g of dry extracts] +0.483 , $\left.\mathrm{R}^{2}=0.994\right)$ and the results were expressed in $\mathrm{mg}$ equivalents of gallic acid per $\mathrm{g}$ of dry extract ( $\mathrm{mg}$ $\mathrm{GA} / \mathrm{g})$.

\section{Determination of total flavonoid content}

The content of total flavonoids in the extracts was determined by the Markham spectrophotometric method [15]. The reaction mixture was prepared by mixing a certain volume of the extract $(2 \mathrm{~mL})$ of concentration $1 \mathrm{mg} / \mathrm{mL}$ with $2 \mathrm{~mL}$ of $2 \%$ methanolic solution of aluminium (III) chloride. The absorbance of the samples was measured at $415 \mathrm{~nm}$ on the spectrophotometer. The total flavonoid content was determined using an equation obtained from a standard rutin calibration curve $(\mathrm{y}=0.0296 \mathrm{x}$ total flavonoid $[\mathrm{mg} \mathrm{RU} / \mathrm{g}$ of dry extracts $\left.]+0.0204, R^{2}=0.9992\right)$ and the results were expressed in $\mathrm{mg}$ equivalents of rutin per $\mathrm{g}$ of dry extract (mg RU/g).

Antioxidant activity

Determination of total anti-oxidative capacity

The total antioxidant activity of extracts was determined by the phosphomolybdenum method spectrophotometrically [22]. The sample solution $(0.3 \mathrm{~mL} ; 1 \mathrm{mg} / \mathrm{mL})$ was mixed with $3 \mathrm{~mL}$ of the reagent solution ( $0.6 \mathrm{M}$ sulfuric acid, $28 \mathrm{mM}$ sodium phosphate and $4 \mathrm{mM}$ ammonium molybdate). The absorbance is measured at $695 \mathrm{~nm}$ on the spectrophotometer. Ascorbic acid (AA) was used as the standard. The total antioxidant capacity in the extracts was calculated using an equation obtained from a standard ascorbic acid calibration curve $(\mathrm{y}=0.006 \mathrm{x}$ total antioxidant capacity [mg AA/g of dry extracts] $0.011, \mathrm{R}^{2}=0.993$ ) and the results expressed in $\mathrm{mg}$ equivalents of ascorbic acid per $\mathrm{g}$ of dry extract (mg AA/g). 
FARMACIA, 2019, Vol. 67, 2

Determination of DPPH free radical scavenging activity

Determination of the ability to neutralize DPPH • $(1,1$ diphenyl-2-picrylhydrazyl) radical was analysed using a spectrophotometric method [13], by preparing a methanolic solution of DPPH radical concentrations of $40 \mu \mathrm{g} / \mathrm{mL}$ in a dark room. The sample solutions and $\mathrm{DPPH}^{-}$were then mixed with $3 \mathrm{~mL}$ of the DPPH radical solution and $2 \mathrm{~mL}$ of the sample solution and such a mixture was left for 30 minutes at room temperature in the dark, after which the absorbance was measured at $517 \mathrm{~nm}$. Ascorbic acid and BHT were used as reference standards. The free radical neutralization capacity was calculated according to the following formula:

Inhibition capacity of the DPPH radical $(\%)=(\mathrm{Ac}-$ As) $/$ Ac $\times 100$,

where the Ac-absorbance of the control solution (negative control), As is the absorbance of the sample solution or standard. The $\mathrm{IC}_{50}$ value $(\mu \mathrm{g} / \mathrm{mL})$, defined as the concentration of extract needed to reduce the DPPH concentration of the radical by $50 \%$, was obtained from the linear regression equation.

Determination of hydroxyl radical scavenging activity In order to determine the ability of the extracts to neutralize the generated $\mathrm{OH}$ radical, it was applied the method described by Smirnoff \& Cumbes with certain modifications [25]. The reaction mixture $(3 \mathrm{~mL})$ contains $1.0 \mathrm{~mL}$ of $1.5 \mathrm{mM} \mathrm{FeSO}_{4}, 0.7 \mathrm{~mL}$ of $6 \mathrm{mM}$ hydrogen peroxide, $0.3 \mathrm{~mL}$ of $20 \mathrm{mM}$ and $1 \mathrm{~mL}$ of the sample solution. The absorbance was measured at measured at $562 \mathrm{~nm}$. Ascorbic acid and BHT were used as reference standards. The percentage of inhibition is calculated according to the equation:

Inhibition capacity of $\mathrm{OH}$ radicals $(\%)=(\mathrm{Ac}-\mathrm{As}) /$ Ac $\times 100$,

where the Ac-absorbance of the control solution (negative control), As is the absorbance of the sample solution or standard. The $\mathrm{IC}_{50}$ value $(\mu \mathrm{g} / \mathrm{mL})$, defined as the concentration of extract needed to reduce the $\mathrm{OH}$ concentration of the radical by $50 \%$, was obtained from the linear regression equation.

Determination of the inhibition of lipid peroxidation The antioxidant activity was determined by a thiocyanate method [8]. The reaction mixture is made with $0.2 \mathrm{~mL}$ of extract samples (serial dilution from 1000 to $16.125 \mu \mathrm{g} / \mathrm{mL}$ ), $0.2 \mathrm{~mL}$ linoleic emulsion (25 $\mathrm{mg} / \mathrm{mL}$ in $99 \%$ ethanol) and $0.4 \mathrm{~mL}$ phosphate buffer $(50 \mathrm{mM}, \mathrm{pH}=7.4)$. The mixture is then incubated in the dark for $72 \mathrm{~h}$ at a temperature of a $40^{\circ} \mathrm{C}$. An aliquot of the reaction mixture of $0.1 \mathrm{ml}$ is taken and $3 \mathrm{~mL}$ of ethanol $(70 \%)$ and $0.1 \mathrm{~mL}$ of ammonium thiocyanate $(30 \%)$ are added. Exactly 3 minutes after adding $0.1 \mathrm{~mL}$ of iron III chloride $(20 \mathrm{mM}$ in $3.5 \%$ hydrochloric acid), the absorbance of the red-coloured mixture is measured at $500 \mathrm{~nm}$. All analyses were carried out three times with the determination of $\mathrm{IC}_{50}$ values.

Reduction capacity

Reducing capacity or reducing power was first described by Oyaizu [20]. One millilitre of samples was mixed with $2.5 \mathrm{~mL}$ phosphate buffer $(0.2 \mathrm{M}, \mathrm{pH} 6.6)$ and $2.5 \mathrm{~mL}$ potassium ferricyanide $(1 \%)$. Then $2.5 \mathrm{~mL}$ of trichloroacetic acid was added to the mixture and spinning the mixture at $3000 \mathrm{rpm}$ for 10 minutes. There were take $2.5 \mathrm{~mL}$ of the upper layer (supernatant), add $2.5 \mathrm{~mL}$ of distilled water and $0.5 \mathrm{~mL}$ of iron three chlorides. The absorbance of the solution was measured at $700 \mathrm{~nm}$ on the spectrophotometer. Ascorbic acid was used as a positive control. Increasing the absorption of the solution shows how much the reducing power is increased.

\section{Cytotoxic activity}

\section{Cell line}

The human cervix adenocarcinoma HeLa S3 cells (ATCC CCL-2.2), human colon adenocarcinoma LS174 cells (ATCC CL-188) and human lung carcinoma A549 cells (ATCC CCL-185) were purchased from American Type Culture Collection (Manassas, VA, United States). Cell line cultured in a nutrient medium RPMI-1640, ( $\mathrm{pH} 7.2)$ with thermally inactivated $\left(56^{\circ} \mathrm{C}\right.$, $30 \mathrm{~min})$ foetal bovine serum $(10 \mathrm{~mL} / 100 \mathrm{~mL})$, Lglutamine $(3 \mathrm{mmol} / \mathrm{L})$, streptomycin $(100 \mathrm{mg} / \mathrm{mL})$, penicillin $(100 \mathrm{lU} / \mathrm{mL})$, and HEPES $(25 \mathrm{mM})$. Cell cultures were cultured in an incubator in an atmosphere saturated with water vapour, in the presence of $5 \%$ $\mathrm{CO}_{2}$, at a temperature of $37^{\circ} \mathrm{C}$.

Experimental design

The tested solution of extracts made in DMSO (stock concentration $=100 \mathrm{mg} / \mathrm{mL}$ ). The applied diluted solutions were concentrations $200,75,25,10 \mu \mathrm{g} / \mathrm{mL}$. Cells for cytotoxic activity (20000 cells/well) and antiproliferative activity (5000 cells/well) in $100 \mu \mathrm{L}$ of a nutrient medium seeded in 96-sterile plates and incubated for 24 hours under an atmosphere of saturated aqueous vapour at $37^{\circ} \mathrm{C}$ and with $5 \% \mathrm{CO}_{2}$. Cells were incubated with test extracts of lichen, as well as controls for the next 24 hours for cytotoxic activity and $72 \mathrm{~h}$ for antiproliferative activity, followed by MTT test. Cells that grow only in the culture medium are used as negative control. As a positive control cis-DDP (cis-diammindihloroplatinum) was used.

MTT test

A MTT standard in vitro test for viability and cell proliferation [17] was used. After the incubation of the cells with the extracts, the cells were washed with $100 \mu \mathrm{L}$ of PBS (phosphate buffer solution) and MTT (20 $\mu \mathrm{L})$ added. The MTT reduction (absorption) measurement was performed spectrophotometrically at a wavelength of $540 \mathrm{~nm}$ on a multichannel spectrophotometer (Multiskan Ascent No354, Thermo Labsystems, Finland). The results are presented as the intensity of MTT reduction relative to negative control. 
FARMACIA, 2019, Vol. 67, 2

The absorbance of the control was taken $100 \%$ and in relation to it was calculated the percentage values of the extracts relative to the control according to the formula:

$\%$ viability $/$ proliferation of extracts $=$ absorbance values of treated cells with extract or positive control/negative absorbance value x 100

Antitumor activity is expressed as an $\mathrm{IC}_{50}$ value. The $\mathrm{IC}_{50}$ value is defined as a concentration that inhibits cell survival by $50 \%$ or inhibits cell growth. The results are presented as the arithmetic mean of the tetraplicates for each concentration of the standard deviation.

\section{Statistical analysis}

All measurements are repeated three times, and the results are displayed as the mean \pm standard error (mean \pm SD). Statistical analyses were performed using Microsoft Excel and SPSS software (version 20) package. One way ANOVA was used to determine differences between mean measurement values, with a statistical significance of $p<0.05$.

\section{Results and Discussion}

The HPLC-UV analysis was used to identify the secondary metabolites present in the Physcia semipinnata lichen. The HPLC chromatograms of the standard substances and the acetone, methanol and aqueous extracts of Physcia semipinnata were recorded at $254 \mathrm{~nm}$ and are presented in Figures 1 and 2.

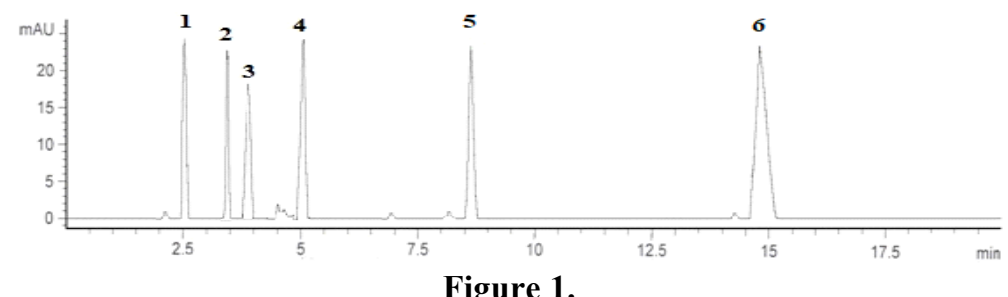

Figure 1.

HPLC chromatogram of the standards used for identification of the compounds present in Physcia semipinnata: 1 - lecanoric acid; 2 - methyl- $\beta$-orcinol carboxylate; 3 - ethyl haematommate; 4 - evernic acid; 5 - obtusic acid; 6 - atranorin
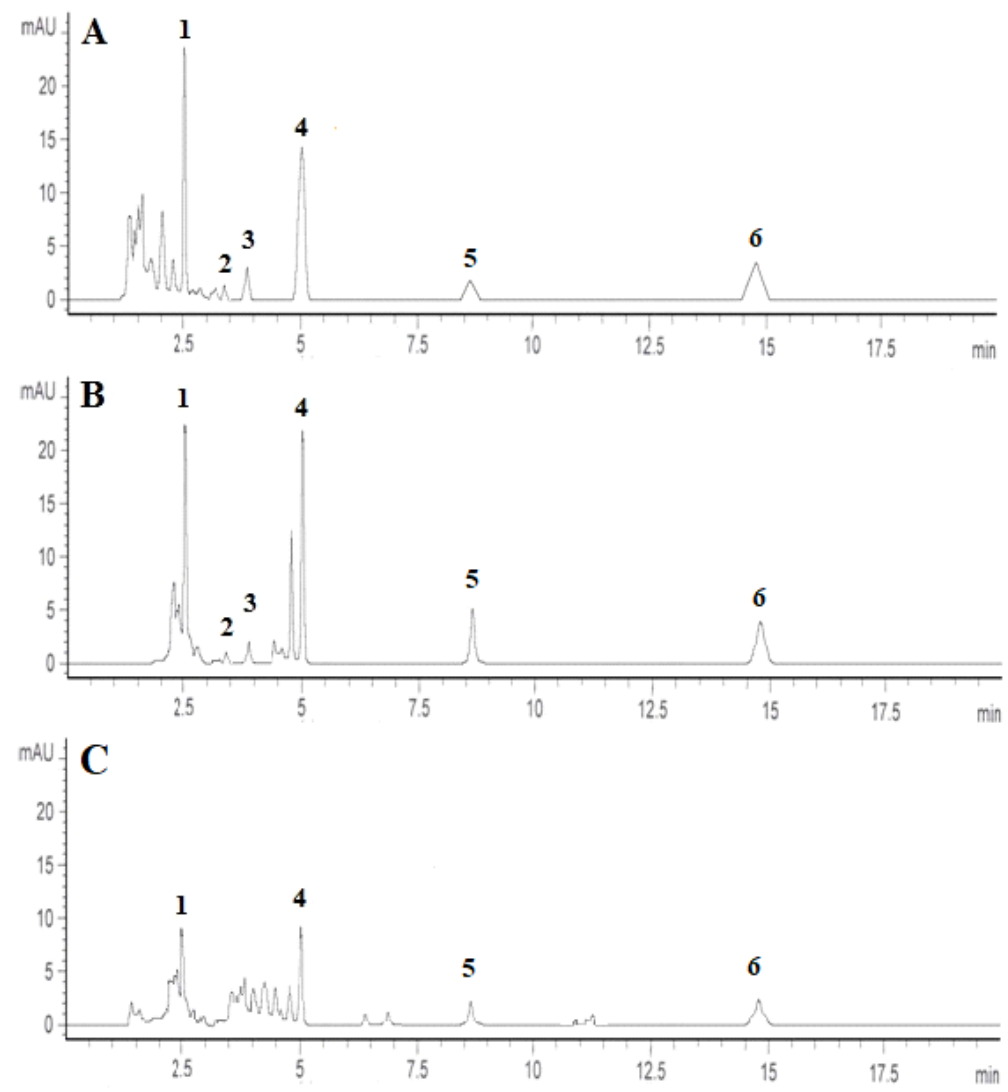

Figure 2.

HPLC chromatograms at $254 \mathrm{~nm}$ of the acetone (A), methanol (B) and aqueous (C) extracts of Physcia semipinnata: 1 - lecanoric acid; 2 - methyl- $\beta$-orcinol carboxylate; 3 - ethyl haematommate; 4 - evernic acid; 5 - obtusic acid; 6 - atranorin 
The results of the HPLC analysis of the acetone, methanolic and aqueous extracts of Physcia semipinnata indicate the presence of six metabolites. Identified metabolites: lecanoric acid (at retention time $t_{R}=2.50 \pm$ $0.10 \mathrm{~min})$, evernic acid $\left(t_{R}=5.08 \pm 0.10 \mathrm{~min}\right)$, obtusic acid $\left(t_{R}=8.62 \pm 0.10 \mathrm{~min}\right)$ and atranorin $\left(t_{R}=14.88 \pm\right.$
$0.10 \mathrm{~min}$ ) belongs to the depsides while methyl- $\beta$ orcinol carboxylate $\left(t_{R}=3.44 \pm 0.10 \mathrm{~min}\right)$ and ethyl haematommate $\left(t_{R}=3.90 \pm 0.10 \mathrm{~min}\right)$ are monocyclic aromatic compounds. The retention times, UV absorbance maxima and the relative abundance of the lichen substances are depicted in Table I.

Table I

Retention time, absorbance maxima and relative abundance of the examined lichen substances

\begin{tabular}{lccccc}
\hline \multirow{1}{*}{ Compound } & $\begin{array}{c}\text { Retention time } \\
\left(\boldsymbol{t}_{\mathbf{R}} \pm \mathbf{S D}\right) *(\mathbf{m i n})\end{array}$ & $\begin{array}{c}\text { Absorbance maxima } \\
(\mathbf{n m})\end{array}$ & \multicolumn{3}{c}{ Relative abundance \% } \\
\cline { 3 - 6 } & $2.50 \pm 0.10$ & $216,268,308$ & Acetone & Methanol & Aqueous \\
\hline Lecanoric acid & $3.44 \pm 0.10$ & $218,267,303$ & 2.81 & 29.11 & 15.51 \\
\hline Methyl- $\beta$-orcinol carboxylate & $3.90 \pm 0.10$ & $240,258,285,337$ & 6.68 & 3.64 & $/$ \\
\hline Ethyl haematommate & $5.08 \pm 0.10$ & $213,270,305$ & 31.87 & 34.80 & 19.01 \\
\hline Evernic acid & $8.62 \pm 0.10$ & $212,278,312$ & 7.65 & 8.39 & 3.15 \\
\hline Obtusic acid & $14.88 \pm 0.10$ & $210,252,321$ & 11.03 & 13.54 & 6.02 \\
\hline Atranorin & & & & & $/$ \\
\hline
\end{tabular}

*Values are the means of three determinations \pm SD

The most abundant components were lecanoric acid $(32.82 \%)$ in the acetone extract and evernic acid in the methanolic (34.80\%) and aqueous (19.01\%) extracts. The amounts of remaining identified metabolites were presented in the following order: atranorin $>$ obtusic acid $>$ ethyl haematommate $>$ methyl $\beta$ orcinol carboxylate. Lecanoric acid have previously been reported from the lichen Parmotrema tinctorum and other lichens genus, but this is the first time to confirm the presence of this metabolite in the lichen Physcia semipinnata [7]. Methyl- $\beta$-orcinol carboxylate and ethyl haematommate are known to be an intermediate product in depside biosynthesis. Depsides are synthesized from their monocyclic precursors by an esterification reaction, and it is possible that several esterases exist [14]. Chemical analysis of $P$. semipinnata showed that all compounds except atranorin were identified in this lichen for the first time. By comparing the tested acetone, methanol and aqueous extracts, the presence of the same metabolites was determined (except in aqueous extract), but the intensity of the signal and the surface below the absorption maximum of certain secondary metabolites it's different, which was in accordance with the ability of the solvents (acetone, methanol and water) to dissolve more or less amounts of these metabolites, according to the principle "similarly in a similar dissolution". Such data indicate the influence of solvents of different polarities on the extraction of individual components from the samples [6]. The distribution patterns of the secondary metabolites are usually taxon-specific and, therefore, have been widely used in lichen taxonomy and systematics [18]. The structures of the detected compounds are shown in Figure 3.<smiles>Cc1cc(OC(=O)c2c(C)cc(O)cc2O)cc(O)c1C(=O)O</smiles>

Lecanoric acid<smiles>COc1cc(C)c(C(=O)Oc2cc(C)c(C(=O)O)c(O)c2)c(O)c1C</smiles>

Obtusic acid<smiles>C=C(OC)c1c(C)cc(O)c(C)c1O</smiles>

Methyl- $\beta$-orcinol carboxylate<smiles>C=C(OCC)c1c(C)cc(O)c(C=O)c1O</smiles>

Ethyl haematommate

Figure 3.<smiles>COc1cc(C)c(C(=O)Oc2cc(C)c(C(=O)O)c(O)c2)c(O)c1</smiles>

Evernic acid<smiles>COC(=O)c1c(C)cc(OC(=O)c2c(C)cc(O)c(C=O)c2O)c(C)c1O</smiles>

Atranorin

Chemicals structures of the identified compounds 
The total polyphenols, flavonoid content and the total antioxidant capacity of examined extracts

\begin{tabular}{ccccc}
\hline \multirow{2}{*}{ Lichen } & Extraction solvent & $\begin{array}{c}\text { Phenolics content } \\
\text { (mg GA/g) }\end{array}$ & $\begin{array}{c}\text { Flavonoids content } \\
\text { (mg RU/g) }\end{array}$ & $\begin{array}{c}\text { Antioxidant capacity } \\
\text { (mg AA/g) }\end{array}$ \\
\hline P semipinnata & Acetone & $51.94 \pm 0.36$ & $11.50 \pm 0.71$ & $44.55 \pm 1.16$ \\
\cline { 2 - 5 } & Methanol & $59.20 \pm 2.13$ & $19.27 \pm 0.37$ & $48.41 \pm 1.38$ \\
\cline { 2 - 5 } & Aqueous & $20.11 \pm 0.48$ & $5.48 \pm 0.57$ & $21.06 \pm 0.74$
\end{tabular}

Values are expressed as mean \pm SD of triplicate measurements; GA - gallic acid equivalents; RU - rutin equivalents; AA - ascorbic acid equivalents

The results of determining the content of the total polyphenols, flavonoids and total antioxidant capacity of the extracts are presented in Table II.

The total polyphenols content of the tested extracts varied from 20.11 to $59.20 \mathrm{mg} \mathrm{GA} / \mathrm{g}$. The amount of total flavonoids of the tested lichens was in the range $5.48-19.27 \mathrm{mg} \mathrm{RU} / \mathrm{g}$. The results showed that the acetone, methanol and aqueous extracts possess antioxidant activity with a total antioxidant capacity range $21.06-48.41 \mathrm{mg} \mathrm{AA} / \mathrm{g}$. The obtained results showed that the methanolic extracts contain the highest

content of the total polyphenols and flavonoids are in accordance with literature data where it has been shown that phenol compounds are more soluble in polar solvents [16]. In our work, there is a mostly positive correlation between the total polyphenols and the results of antioxidative activity testing. These results agree with the literature [9].

As it can be seen in the Table III, DPPH scavenging, $\mathrm{OH}$ scavenging and inhibition lipid peroxidation activity of the tested extracts were generally lower compared to the standard substances.

Table III

The antioxidant activity of examined extracts of the lichen Physcia semipinnata

\begin{tabular}{lcccc}
\hline \multirow{2}{*}{$\begin{array}{c}\text { Lichen } \\
\text { species }\end{array}$} & $\begin{array}{c}\text { Extraction } \\
\text { solvent }\end{array}$ & \multicolumn{3}{c}{$\mathbf{I C}_{\mathbf{5 0}}(\boldsymbol{\mu g} \mathbf{g} \mathbf{m L})$} \\
\cline { 2 - 5 } P. semipinnata & DPPH scavenging activity & OH radical scavenging activity & Inhibition lipid peroxidation \\
\cline { 2 - 5 } & Acetone & $99.19 \pm 1.02$ & $291.64 \pm 4.07$ & $134.23 \pm 4.55$ \\
\cline { 2 - 5 } & Methanol & $118.02 \pm 1.33$ & $258.32 \pm 2.12$ & $142.93 \pm 2.90$ \\
\cline { 2 - 5 } & Aqueous & $307.05 \pm 0.82$ & $565.75 \pm 7.78$ & $199.56 \pm 5.79$ \\
\hline Ascorbic acid & & $6.05 \pm 0.34$ & $150.55 \pm 2.31$ & $>1000$ \\
\hline BHT & & $15.61 \pm 1.26$ & $33.92 \pm 0.79$ & $1.00 \pm 0.23$
\end{tabular}

Values are expressed as mean \pm SD of triplicate measurements; AA - ascorbic acid equivalents; BHT - Butylhydroxytoluene

The assessment of the antioxidant activity showed that all tested extracts were able to scavenge DPPH radical. The acetone extract of $P$. semipinnata showed highest DPPH free radical scavenging activity $\left(\mathrm{IC}_{50}=\right.$ $99.19 \mu \mathrm{g} / \mathrm{mL}$ ) than other tested extracts, while the aqueous extract of $P$. semipinnata showed the lowest activity $\left(\mathrm{IC}_{50}=307.05 \mu \mathrm{g} / \mathrm{mL}\right)$. The results of the hydroxyl radical scavenging activity of the tested extracts showed that the highest activity had the methanolic extract of P. semipinnata $\left(\mathrm{IC}_{50}=258.32\right.$ $\mu \mathrm{g} / \mathrm{mL}$ ), while the aqueous extract of $P$. semipinnata showed the lowest activity $\left(\mathrm{IC}_{50}=565.75 \mu \mathrm{g} / \mathrm{mL}\right)$. Results demonstrated that tested extracts exhibited inhibition lipid peroxidation (from $\mathrm{IC}_{50}$ values acetone extract $=134.23$ to aqueous extract $199.56 \mu \mathrm{g} / \mathrm{mL}$ ). The results of the reducing power of the tested lichen extracts are shown in Table IV, where the examined extracts had slightly less activity compared to ascorbic acid.

Reducing power of examined extracts of the lichen Physcia semipinnata and ascorbic acid

\begin{tabular}{|c|c|c|c|c|c|}
\hline \multirow[t]{2}{*}{ Lichen extract } & \multicolumn{5}{|c|}{ Absorbance (700 nm) } \\
\hline & $1000 \mu \mathrm{g} / \mathrm{mL}$ & $500 \mu \mathrm{g} / \mathrm{mL}$ & $250 \mu \mathrm{g} / \mathrm{mL}$ & $125 \mu \mathrm{g} / \mathrm{mL}$ & $62.5 \mu \mathrm{g} / \mathrm{mL}$ \\
\hline P. semipinnata $*^{A}$ & $0.21 \pm 0.008$ & $0.121 \pm 0.004$ & $0.061 \pm 0.001$ & $0.038 \pm 0.002$ & $0.019 \pm 0.006$ \\
\hline P. semipinnata ${ }^{M}$ & $0.099 \pm 0.004$ & $0.063 \pm 0.002$ & $0.03 \pm 0.007$ & $0.023 \pm 0.005$ & $0.012 \pm 0.001$ \\
\hline P. semipinnata $*^{A q}$ & $0.032 \pm 0.009$ & $0.022 \pm 0.006$ & $0.016 \pm 0.001$ & $0.007 \pm 0.002$ & $0.002 \pm 0.001$ \\
\hline Ascorbic acid & $2.113 \pm 0.032$ & $1.654 \pm 0.021$ & $0.0957 \pm 0.008$ & $0.0478 \pm 0.004$ & $0.0247 \pm 0.004$ \\
\hline
\end{tabular}

In various antioxidant activities, there was a statistically significant difference between the extracts and the control $(\mathrm{p}<0.05)$. In the case of the lichen Physcia semipinnata, the acetone extract had higher phenol content, but a lower reduction power than the methanol extract, which suggests that the antioxidant activity of the tested extract can be attributed to the presence of non-phenolic constituents. This fact is confirmed by earlier studies that have shown that total polyphenols content and antioxidant activity are not always in a positive correlation [19]. In our work, it has been shown that the intensity of the anti-oxidative activity depends on the solvent that was used for extraction. The differences in the antioxidant activity of various 
FARMACIA, 2019, Vol. 67, 2

solvents may be the result of different capabilities to extract bioactive substances [1]. Our tested extracts contain lecanoric acid, evernic acid and atranorin for which it have been shown to be exhibition of a significant antioxidant activity (DPPH scavenging, superoxide anion scavenging and reducing power) $[11,12]$, that is lower than the activity shown for our examined acetone extract of lichen $P$. semipinnata. This can be explained by the synergistic effects of individual metabolites belonging to depsidone and depside groups. The antioxidant effect of some other lichens has also been studied by other researchers. Compared with their results, the results of this research suggest that the tested samples showed a relatively powerful antioxidant activity [21].

The results of the study of viability and proliferation of HeLa cells after the action of the extracts showed that the highest cytotoxic/cytostatic activity was exhibited by the acetone extract of the $P$. semipinnata
$\left(\mathrm{IC}_{50}=76.61 \mu \mathrm{g} / \mathrm{mL}\right.$ after $24 \mathrm{~h}$ of incubation; $\mathrm{IC}_{50}=$ $43.45 \mu \mathrm{g} / \mathrm{mL}$ after $72 \mathrm{~h}$ incubation). Also, the highest cytotoxic activity against LS174 and A549 cell lines exhibited the acetone extract $\left(\mathrm{IC}_{50}=78.93 \mu \mathrm{g} / \mathrm{mL}\right.$ and $71.71 \mu \mathrm{g} / \mathrm{mL}$ after $72 \mathrm{~h}$ incubation). The cytotoxic activity of depsides may be in part due to the presence of a $\mathrm{COOH}$ group on $\mathrm{C} 1$ and an $\mathrm{OH}$ group on $\mathrm{C} 2$. Very good cytotoxic activity against malignant Fem-x and LS174 cells showed depside atranorin and evernic acid. An increase in cells containing sub-G1 amounts of DNA was observed, indicating that evernic acid was inducing cell death $[11,23]$. Also, in recent years it has been shown that lecanoric acid has moderate antitumor activity against some malignant cell lines (MCF-7 breast carcinoma, 786-0 kidney carcinoma, B16-F10 murine melanoma, FemX and LS174) tested, consistent with the induction of apoptosis in a cell cycle-dependent manner [2, 12].

Cytotoxic activity of examined extracts on the HeLa S3, LS174 and A549 cells line (after $24 \mathrm{~h}$ and $72 \mathrm{~h}$ incubation)

\begin{tabular}{lcccccc}
\multirow{2}{*}{$\begin{array}{l}\text { extract } \\
\end{array}$} & \multicolumn{7}{c}{$\boldsymbol{I} \boldsymbol{C}_{\boldsymbol{5} \mathbf{0}}(\boldsymbol{\mu g} / \mathbf{m L})$} \\
\cline { 2 - 7 } & $\mathbf{2 4} \mathbf{h}$ & $\mathbf{7 2} \mathbf{~ h}$ & $\mathbf{2 4} \mathbf{~ h}$ & $\mathbf{7 2} \mathbf{~}$ & $\mathbf{2 4} \mathbf{~}$ & A549 \\
\hline Acetone & $76.61 \pm 9.10$ & $43.45 \pm 0.79$ & $188.89 \pm 6.18$ & $78.93 \pm 0.53$ & $\mathbf{7 2} \mathbf{~ h}$ \\
\hline Methanol & $122.56 \pm 8.31$ & $85.05 \pm 5.18$ & $>200$ & $158.14 \pm 4.33$ & $>200$ & $128.68 \pm 1.3$ \\
\hline Aqueous & $>200$ & $191.56 \pm 4.98$ & $>200$ & $>196.05 \pm 7.45$ & $>200$ & $>200$ \\
\hline Cis-DDP & $2.16 \pm 0.67$ & $0.78 \pm 0.21$ & $5.89 \pm 0.92$ & $2.48 \pm 0.32$ & $5.6 \pm 1.21$ & $3.52 \pm 0.28$ \\
\hline
\end{tabular}

Values are expressed as mean \pm SD of triplicate measurements

\section{Conclusions}

This is the first research dealing with detailed chemical composition, antioxidant and cytotoxic activities of the extracts of Physcia semipinnata. Identified secondary metabolites have been already reported in other lichen species, this is the first time that they were reported in Physcia semipinnata. The acetone and methanol extracts of the lichen showed significant antioxidant and cytotoxic activities in different assays in vitro. The present study provides data supporting the use of $P$. semipinnata extracts as natural antioxidant agents and confirms that this lichen represents a significant source of phenolic compounds.

\section{Acknowledgement}

This research was supported by Ministry of Education and Science of Serbia, projects number: 172015 and 173032.

\section{References}

1. Behera BC, Verma N, Sonone A, Makhija U, Antioxidant and antibacterial activities of lichen Usnea ghattensis in vitro. Biotechnol Lett., 2005; 27(14): 991-995.

2. Bogo D, Matos MDFC, Honda NK, Pontes EC, Oguma $\mathrm{PM}$, da Silva Santos EC, Nomizo A, In vitro anti- tumour activity of orsellinates. $Z$ Naturforsch $C, 2010$; 65(1-2), 43-48.

3. Boustie J, Grube M, Lichens - a promising source of bioactive secondary metabolites. Plant Genet Resour., 2005; 3(2): 273-287.

4. Calcott MJ, Ackerley DF, Knight A, Keyzers RA, Owen JG, Secondary metabolism in the lichen symbiosis. Chem Soc Rev., 2018; 47(5): 1730-1760.

5. Dobson FS, Lichens. An illustrated guide to the British and Irish species, $6^{\text {th }}$ ed. Richmond Publishing Co. London. 2011.

6. Durling NE, Catchpole OJ, Grey JB, Webby RF, Foo LY, Perry NB, Extraction of phenolics and essential oil from dried sage (Salvia officinalis) using ethanol water mixtures. Food Chem., 2007; 101(4): 1417-1424.

7. Gomes AT, Honda NK, Roese FM, Muzzi RM, Marques MR, Bioactive derivatives obtained from lecanoric acid, a constituent of the lichen Parmotrema tinctorum (Nyl.) Hale (Parmeliaceae). Rev Bras Farmacogn., 2002; 12: 74-75.

8. Hsu CK, Chiang BH, Chen YS, Yang JH, Liu CL, Improving the antioxidant activity of buckwheat (Fagopyrum tataricm gaertn) sprout with trace element water. Food Chem., 2008; 108(2): 633-641.

9. Katalinic V, Milos M, Kulisic T, Jukic M. Screening of 70 medicinal plant extracts for antioxidant capacity and total phenols. Food Chem., 2006; 94(4): 550-557.

10. Kosanić M, Ristić S, Stanojković T, Manojlović N, Ranković B, Extracts of five Cladonia lichens as sources of biologically active compounds. Farmacia, 2018; 66(4): 644-651. 
11. Kosanić M, Manojlović N, Janković S, Stanojković T, Ranković B, Evernia prunastri and Pseudevernia furfuraceae lichens and their major metabolites as antioxidant, antimicrobial and anticancer agents. Food Chem Toxicol., 2013; 53: 112-118.

12. Kosanić M, Ranković B, Stanojković T, Rančić A, Manojlović N, Cladonia lichens and their major metabolites as possible natural antioxidant, antimicrobial and anticancer agents. LWT Food Sci Technol., 2014; 59(1): 518-525.

13. Kumarasamy Y, Byres M, Cox PJ, Jaspars M, Nahar L, Sarker SD, Screening seeds of some Scottish plants for free radical scavenging activity. Phytother Res., 2007; 21(7): 615-621.

14. Legaz ME, de Armas R, Vicente C. Bioproduction of depsidones for pharmaceutical purposes. In Drug Development - A Case Study Based Insight into Modern Strategies. InTech. 2011.

15. Meda A, Lamien CE, Romito M, Millogo J, Nacoulma OG, Determination of the total phenolic, flavonoid and proline contents in Burkina Fasan honey, as well as their radical scavenging activity. Food Chem., 2005; 91(3): 571-577.

16. Mohsen SM, Ammar AS, Total phenolic contents and antioxidant activity of corn tassel extracts. Food Chem., 2009; 112(3): 595-598.

17. Mosmann T, Rapid colorimetric assay for cellular growth and survival: application to proliferation and cytotoxicity assays. J Immunol Meth., 1983; 65(1-2): 55-63.

18. Nelsen MP, Gargas A, Phylogenetic distribution and evolution of secondary metabolites in the lichenized fungal genus Lepraria (Lecanorales: Stereocaulaceae). Hedwigia, 2008; 86(1-2): 115-131.

19. Odabasoglu F, Aslan A, Cakir A, Suleyman H, Karagoz Y, Bayir Y, Halici M, Antioxidant activity, reducing power and total phenolic content of some lichen species. Fitoterapia, 2005; 76(2): 216-219.

20. Oyaizu M, Studies on products of browning reaction. Jpn J Nutr., 1986; 44(6): 307-315.

21. Popovici V, Bucur L, Popescu A, Caraiane A, Badea $\mathrm{V}$, Determination of the content in usnic acid and polyphenols from the extracts of Usnea barbata L. and the evaluation of their antioxidant activity. Farmacia, 2018; 66(2): 337-341.

22. Prieto P, Pineda M, Aguilar M, Spectrophotometric quantitation of antioxidant capacity through the formation of a phosphomolybdenum complex: specific application to the determination of vitamin E. Anal Biochem., 1999; 269(2): 337-341.

23. Ranković B, Kosanić M, Manojlović N, Rančić A, Stanojković T, Chemical composition of Hypogymnia physodes lichen and biological activities of some its major metabolites. Med Chem Res., 2014; 23(1): 408-416.

24. Singleton VL, Orthofer R, Lamuela-Raventós RM, Analysis of total phenols and other oxidation substrates and antioxidants by means of Folin-Ciocalteu reagent. Methods Enzymol., 1999; 299: 152-178.

25. Smirnoff N, Cumbes QJ, Hydroxyl radical scavenging activity of compatible solutes. Phytochemistry, 1989; 28(4): 1057-1060.

26. Wirth V. Die Flechten Baden-Würtembergs, Verbreitungsatlas, 1\&2. Eugen Ulmer GmbH\&Co: Stuttgart, Germany. 1995.

27. Yamamoto Y, Kinoshita Y, Matsubara H, Screening of biological activities and isolation of biologicalactive compounds from lichens. Recent Res Dev Phytochem., 1998; 2: 23-34.

28. Yuan H, Ma Q, Ye L, Piao G, The traditional medicine and modern medicine from natural products. Molecules, 2016; 21(5): 559. 